\title{
Construction of the Evaluation System of Regional Innovation in Science and Technology in Jiuquan Using Fuzzy AHP
}

\section{Xie ZHANG}

College of Economics and Management, Gansu University of Traditional Chinese Medcine, Lanzhou, China

Li YANG

JiuQuan vocational and technical college, Jiuquan, China

Jinxue LI

Jiuquan Science and technology information institute, Jiuquan, China

Mingwei WU

College of Economics and Management, Gansu University of Traditional Chinese Medcine, Lanzhou, China

\begin{abstract}
In this article, how to construct this evaluation system of Regional Innovation in science and technology based on AHP was discussed, and its index weight of the evaluation system was calculated, which aimed at providing a reference for the decision- making and development of related policies in Jiuquan regional innovation in science and technology by constructing this kind of evaluation system.
\end{abstract}

KEYWORD: regional; innovation in science and technology; evaluation system

"The innovation ability in regional science and technology refers to a capacity to promote the regional economic development in a particular area by making full use of the interaction among its scientific and technological elements. Through its effective use of the resources of regional scientific and technological innovation, it regulates the cooperation and competition in science and technology among the various areas, achieves an efficient configuration and structural optimization of the resources (talent, knowledge, inputs) in the scientific technological innovation within a region. Also, it has greatly expanded the innovation activities and the application, promotion and popularization of the scientific technological accomplishments and created the developed the competitive advantages of the region, thus promoting the development of the regional economic."[1] With the rapid development of the domestic economy and technology, the regional innovation evaluation in science and technology has become one of the integral factors in the programs and achievements of the areas of regional science and technology.

1 TO CONSTRUCT THE EVALUATION SYSTEM OF INNOVATION IN THE SCIENCE AND TECHNOLOGY IN JIUQUAN AREA BASED ON THE ANALYTIC HIERARCHY PROCESS

In this paper, the AHP was used to comprehensively analyze the evaluation system of the regional innovation in the science and technology in Jiuquan. As an analytical method of being structured, systematic, hierarchical and combining qualitative and quantitative, it divides a complex problem into several constituent elements, and groups these elements according to their relations of domination, and then by using the method of pair comparison to determine the relative importance of the decisionmaking scheme, forming an ordered hierarchical structure.

The comprehensive analysis of the evaluation system of the regional innovation in science and technology in Jiuquan is a multi-criteria, comprehensive, multifactorial and complex issue. In this paper, the main factors and the basic requirements of the evaluation system of regional innovation in Jiuquan of Gansu Province were identified into three criteria and six indexes to construct its hierarchical model, among which, the target layer (A) was the evaluation system of the regional innovation in the science and technology in Jiuquan; Criteria layer (C) consisted of three aspects: output of scientific and technological innovation $\mathrm{C} 1$, input of scientific and technological innovation $\mathrm{C} 2$ and foundation of scientific and technological innovation $\mathrm{C} 3$; program level $(\mathrm{P})$ included six contents: output and diffusion of knowledge $\mathrm{P}_{1}$, output and diffusion of technology $\mathrm{P}_{2}$, input of human resources $\mathrm{P}_{3}$, funding for scientific and technological innovation $\mathrm{P}_{4}$, human resources for science and technology $\mathrm{P}_{5}$, material conditions of research and awareness of scientific andtechnological innovation $\mathrm{P}_{6}$. 
According to the analysis, following the basic principles of AHP, to construct a hierarchical structure model of Evaluation System of Regional
Innovation in Science and Technology in Jiuquan (shown in Figure 1).

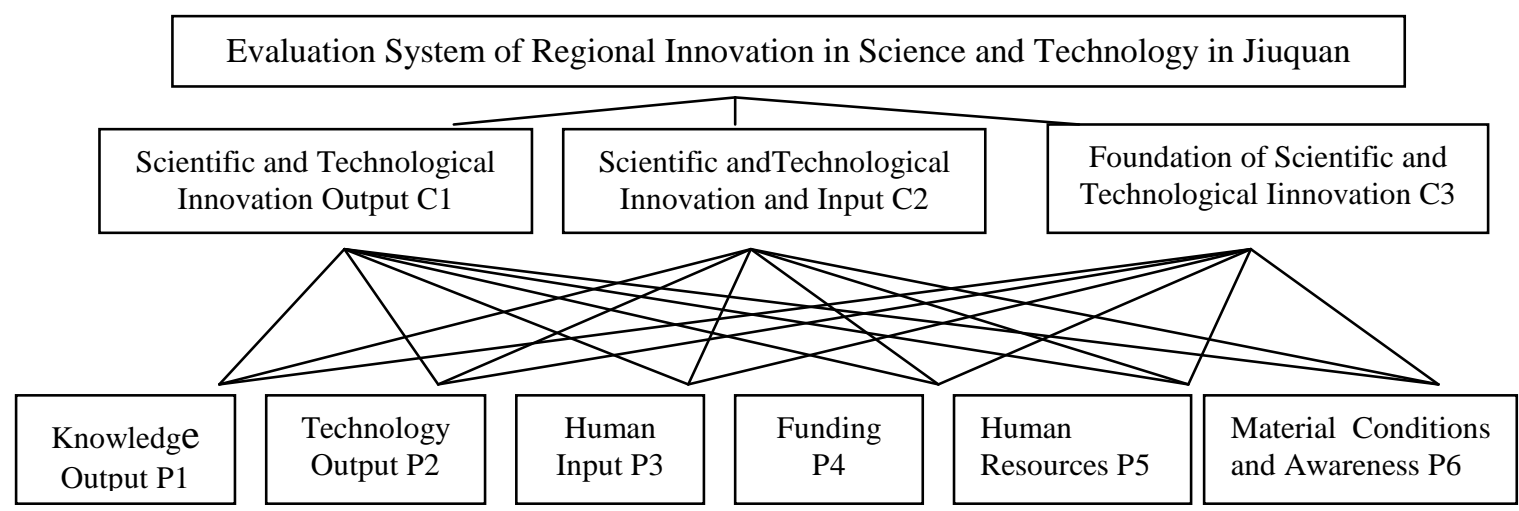

Figure 1: hierarchical model of evaluation system of regional innovation in science and technology in Jiuquan.

2 TO CALCULATE THE INDEX WEIGHT OF THE EVALUATION SYSTEM OF REGIONAL INNOVATION IN SCIENCE AND TECHNOLOGY IN JIUQUAN, GANSU

According to the hierarchical model structure of evaluation system of regional innovation in science and technology in Jiuquan above, the experts rich in both experience and ability to judge gave a scientific and rational judgment to the relative importance of every element in each level of the hierarchical model. (The methods of hierarchical judgment scaling are shown in Table 1).

Table 1.Matrix of judgment

\begin{tabular}{|c|l|l|}
\hline The relative importance & Definition & Explanation \\
\hline 1 & equally important & Factors $\mathrm{Bi}$ and $\mathrm{Bj}$ are equally important . \\
\hline 3 & slightly important & Factor $\mathrm{Bi}$ is a bit more important than factor $\mathrm{Bj}$. \\
\hline 5 & very important & Factor $\mathrm{Bi}$ is more important than factor $\mathrm{Bj}$. \\
\hline 7 & obviously important & Factor $\mathrm{Bi}$ is more important than factors $\mathrm{Bj}$ significantly. \\
\hline 9 & absolutely important & Factor $\mathrm{Bi}$ is more important than factor $\mathrm{Bj}$ absolutely \\
\hline $2,4,6,8$ & between the two adjacent importance \\
\hline Reciprocal & $\begin{array}{l}\text { With the comparison of Bi and } \mathrm{Bj}, \text { the judgement Bij was obtained, so by comparing } \mathrm{Bj} \text { and } \mathrm{Bi}, \text { the } \\
\text { judgement Bji = } 1 / \mathrm{Bij} \text { was determined. }\end{array}$ \\
\hline
\end{tabular}

Based on the judgment matrix, the single- level sort was as follows:

Table 2.Single-level sort of output and diffusion of knowledge $\left(\mathrm{P}_{1}\right)$

\begin{tabular}{|c|c|c|c|c|}
\hline output and diffusion of knowledge P1 & $\mathrm{C}_{1}$ & $\mathrm{C}_{2}$ & $\mathrm{C}_{3}$ & sort value of importance \\
\hline output of scientific and technological innovation $\mathrm{C} 1$ & 1 & $1 / 7$ & $1 / 5$ & 0.077 \\
\hline input of scientific and technological innovation $\mathrm{C} 2$ & 7 & 1 & $7 / 5$ & 0.539 \\
\hline foundation of scientific and technological innovation C3 & 5 & $5 / 7$ & 1 & 0.385 \\
\hline
\end{tabular}

$\lambda_{\max }=3.000, \mathrm{CI}=0.000, \mathrm{RI}=0.579, \mathrm{CR}=0.00<0.10$

Table 3.Single-level sort of output and diffusion of technology $\left(\mathrm{P}_{2}\right)$

\begin{tabular}{|l|c|c|c|c|}
\hline output and diffusion of technology P2 & $\mathrm{C}_{1}$ & $\mathrm{C}_{2}$ & $\mathrm{C}_{3}$ & sort value of importance \\
\hline output of scientific and technological innovation C1 & 1 & $1 / 3$ & $1 / 5$ & 0.111 \\
\hline input of scientific and technological innovation C2 & 3 & 1 & $3 / 5$ & 0.333 \\
\hline foundation of scientific and technological innovation C3 & 5 & $5 / 3$ & 1 & 0.556 \\
\hline
\end{tabular}

$\lambda_{\max }=3.000, \mathrm{CI}=0.000, \mathrm{RI}=0.579, \mathrm{CR}=0.00<0.10$ 
Table 4. Single-level sort of human resources $\left(\mathrm{P}_{3}\right)$

\begin{tabular}{|c|c|c|c|c|}
\hline output of human resources P3 & $\mathrm{C}_{1}$ & $\mathrm{C}_{2}$ & $\mathrm{C}_{3}$ & sort value of importance \\
\hline input of scientific and technological innovation $\mathrm{C} 1$ & 1 & 3 & 5 & 0.659 \\
\hline input of scientific and technological innovation $\mathrm{C} 2$ & $1 / 3$ & 1 & $3 / 5$ & 0.156 \\
\hline foundation of scientific and technological innovation C3 & $1 / 5$ & $5 / 3$ & 1 & 0.185 \\
\hline
\end{tabular}

$\lambda_{\max }=3.000, \mathrm{CI}=0.000, \mathrm{RI}=0.579, \mathrm{CR}=0.00<0.10$

Table 5.Single-level sort of funding input for scientific and technological innovation $\left(\mathrm{P}_{4}\right)$

\begin{tabular}{|l|c|c|c|c|}
\hline funding input for scientific and technological innovation p4 & $\mathrm{C}_{1}$ & $\mathrm{C}_{2}$ & $\mathrm{C}_{3}$ & sort value of importance \\
\hline output of scientific and technological innovation C1 & 1 & $2 / 5$ & $2 / 9$ & 0.125 \\
\hline input of scientific and technological innovation C2 & $5 / 2$ & 1 & $5 / 9$ & 0.313 \\
\hline foundation of scientific and technological innovation C3 & $9 / 2$ & $9 / 5$ & 1 & 0.563 \\
\hline
\end{tabular}

$\lambda_{\max }=3.000, \mathrm{CI}=0.000, \mathrm{RI}=0.579, \mathrm{CR}=0.00<0.10$

Table 6.Single-level sort of human resources $\left(\mathrm{P}_{5}\right)$

\begin{tabular}{|l|c|c|c|c|}
\hline human resources of science and technology P5 & $\mathrm{C}_{1}$ & $\mathrm{C}_{2}$ & $\mathrm{C}_{3}$ & sort value of importance \\
\hline input of scientific and technological innovation C1 & 1 & 1 & $1 / 9$ & 0.091 \\
\hline input of scientific and technological innovation C2 & 1 & 1 & $1 / 9$ & 0.091 \\
\hline foundation of scientific and technological innovation C3 & 9 & 9 & 1 & 0.818 \\
\hline
\end{tabular}

$\lambda_{\max }=3.000, \mathrm{CI}=0.000, \mathrm{RI}=0.579, \mathrm{CR}=0.00<0.10$

Table 7.Single-level sort of material conditions of research and awareness of scientific andtechnological innovation $\left(\mathrm{P}_{6}\right)$

\begin{tabular}{|l|c|c|c|c|}
\hline $\begin{array}{l}\text { material conditions of research and awareness of scientific and } \\
\text { technological innovation P6 }\end{array}$ & $\mathrm{C}_{1}$ & $\mathrm{C}_{2}$ & $\mathrm{C}_{3}$ & sort value of importance \\
\hline input of scientific and technological innovation C1 & 1 & 3 & 3 & 0.601 \\
\hline input of scientific and technological innovation C2 & $1 / 3$ & 1 & 1 & 0.201 \\
\hline foundation of scientific and technological innovation C3 & $1 / 3$ & 1 & 1 & 0.201 \\
\hline
\end{tabular}

$\lambda_{\max }=3.000, \mathrm{CI}=0.000, \mathrm{RI}=0.579, \mathrm{CR}=0.00<0.10$

According to the results of the single-level sort, to construct the general hierarchical sort of evaluation system of regional innovation in science and technology in Jiuquan.

Table 8.General sort of the comprehensive evaluation

\begin{tabular}{|c|c|c|c|c|c|c|c|}
\hline $\mathrm{C}$ & $\begin{array}{l}\text { output and } \\
\text { diffusion of } \\
\text { knowledge } \\
\quad\left(\mathrm{P}_{1}\right)\end{array}$ & $\begin{array}{l}\text { output and } \\
\text { diffusion of } \\
\text { knowledge } \\
\left(\mathrm{P}_{2}\right)\end{array}$ & $\begin{array}{l}\text { output } \\
\text { of human } \\
\text { resources } \\
\quad\left(\mathrm{P}_{3}\right)\end{array}$ & $\begin{array}{c}\text { Funding } \\
\text { input for } \\
\text { scientific } \\
\text { and technological } \\
\text { innovation }\left(\mathrm{P}_{4}\right)\end{array}$ & $\begin{array}{c}\text { human } \\
\text { resources of } \\
\text { science and } \\
\text { technology } \\
\left(\mathrm{P}_{5}\right)\end{array}$ & $\begin{array}{c}\text { material } \\
\text { conditions of } \\
\text { research and } \\
\text { awareness of } \\
\text { scientific and } \\
\text { technological } \\
\text { innovation } \\
\left(\mathrm{P}_{6}\right)\end{array}$ & $\begin{array}{c}\text { general } \\
\text { sort of the } \\
\text { comprehend- } \\
\text { sive } \\
\text { evaluation }\end{array}$ \\
\hline $\begin{array}{l}\text { input of scientific } \\
\text { and technological } \\
\text { innovation }(\mathrm{C} 1)\end{array}$ & 0.077 & 0.111 & 0.659 & 0.125 & 0.091 & 0.600 & 0.243 \\
\hline $\begin{array}{l}\text { input of scientific } \\
\text { and technological } \\
\text { innovation }(\mathrm{C} 2)\end{array}$ & 0.538 & 0.333 & 0.156 & 0.313 & 0.091 & 0.200 & 0.293 \\
\hline $\begin{array}{l}\text { foundation of } \\
\text { scientific and } \\
\text { technological } \\
\text { innovation }(\mathrm{C} 3)\end{array}$ & 0.385 & 0.556 & 0.185 & 0.562 & 0.818 & 0.200 & 0.434 \\
\hline
\end{tabular}

From Table 8, we know that part of the right value of $\mathrm{C} 1$ was 0.243 , and the program sort ranked the third; part of the right value of $\mathrm{C} 2$ was 0.293 , and the program sort ranked the second; part of the 
right value of C3 was 0.434 , the program sort ranked the first.

\section{CONCLUSIONS AND DISCUSSION}

Based on the process of the analysis and calculation above, the following basic conclusions could be drawn: Currently, it should be took into the consideration firstly to strengthen the foundation of the progress of regional innovation in science and technology during the constructing of regional innovation system in science and technology in Jiuquan of Gansu Province, including the development of human resources in science and technology (In general, the ability and level of innovation depends on its quality, quantity , distribution and usage of human resources in science and technology.), the creation of material conditions of the research (which reflects its financial resources, equipment and support units of the innovation ability), the strengthening and popularity of scientific and technological awareness (which reflects the awareness and ability to involve the innovation and whether there is the innovation initiative and forward-looking), etc; Secondly, the input of human resources in science and technology should be considered too (which refers to the development input for the professional and technical resources like professionals engaged in the relevant scientific and technological research, technological development, education and management[2]), and the capital investment in the scientific and technological activities (The assurance of the innovation capability is not only to guarantee a certain amount, but also to ensure a certain degree of intensity.); Thirdly, it should also be considered to enhance the output capabilities of regional knowledge and technology, and the capacity of technical diffusion as well, which can reflect the innovation capacities, levels and performances.
Furthermore, the environment of the regional innovation in science and technology should continue to be improved, too.

In the practice of the management of scientific and technological innovation, generally there will be such similar problems as management decisions. So, here in this paper, the managing and decisionmaking authorities of scientific and technological innovation in Jiuquan of Gansu have been provided some suggestions about how to construct the regional innovation system of science and technology, based on such aspects as human resources of science and technology, material conditions of research, awareness of scientific and technological innovation, input of human resources in science and technology, capital investment of scientific and technological innovation, outputs and diffusion of knowledge and technology, etc., which have certain referential values for Jiuquan to solve its problems in scientific and technological innovation. And, of course, there are still some specific indexes which should be further studied as well.

\section{ACKNOWLEDGEMENT}

Thanks for the science and technology support Project of Jiuquan, China (201426).

\section{REFERENCES}

[1] Liu Shuang. Construction of Index System of Regional Innovation in Science and Technology. Heilongjiang Finance, 2011, (10): 19-21.

[2] Gao Feng, Dang Yaru. Construction of Index System of the Evaluation of Scientific and Technological Iinnovation in the Aviation Research on the Scientific and Technological Management, 2005, (8): 35-37. 